Канд. техн. наук О.А. Логвіненко, acn. K.B. Acmaxoвa,

B.I. Громов

\title{
ПОРІВНЯЛЬНИЙ АНАЛІЗ \\ ПРУЖНО-ДИСИПАТИВНИХ ПАРАМЕТРІВ МЕХАНІЗМІВ ГАЗОРОЗПОДІЛУ ТЕПЛОВОЗНИХ ДИЗЕЛІВ Д8О ТА Д49
}

\author{
Представив д-р техн. наук, професор В.І. Мороз
}

\begin{abstract}
Постановка проблеми i аналіз останніх досліджень $\mathbf{y}$ напрямку іï вирішення. Залізничний транспорт займає провідне місце у задоволенні потреб виробничої сфери та населення у перевезеннях, $\epsilon$ важливим фактором забезпечення соціально-економічного розвитку України, укріплення іii зовнішньоекономічних зв'язків. Досягнення високих економічних показників його роботи пов'язане 3 необхідністю підвищення технікоекономічних показників тягового рухомого складу (ТРС), зокрема тепловозів. Відповідно до основних положень
\end{abstract} державної цільової програми реформування залізничного транспорту на 2010-2019 роки (затверджено постановою Кабінету Міністрів України від 16 грудня 2009 р. № 1390 (в редакції постанови Кабінету Міністрів України від 26 жовтня 2011 р. № 1106)) та Транспортної стратегії України на період до 2020 року (схвалено розпорядженням Кабінету Міністрів України від 20 жовтня 2010 р. № 2174-p) одним із пріоритетних напрямків розвитку залізниць $є$ підвищення паливної економічності та надійності енергетичних установок тепловозів. Це обумовлює необхідність забезпечення парків магістральних i маневрових тепловозів надійними та довговічними в експлуатації дизелями з високими показниками паливної економічності та екологічності [1].

Одним 3 найважливіших напрямків вирішення цієї задачі, поряд з поліпшенням процесів сумішоутворення, згоряння, теплопередачі, $\epsilon$ удосконалення газообмінних процесів у циліндрах двигуна, що досягається за рахунок забезпечення ефективного функціонування кулачкових механізмів газорозподілу (КМГР) [2].

Аналіз останніх досліджень і публікацій показав, що у вирішенні задачі досягнення високих значень часу-перерізу клапанів i забезпечення потрібних фаз газорозподілу одна 3 головних ролей відводиться моделюванню, аналізу i контролю динамічних процесів, які протікають у КМГР [3,4]. Тому при проведенні таких досліджень доцільно використовувати описані в роботах [5,6] динамічні моделі (ДМ), що в свою чергу потребує визначення відповідних пружнодисипативних параметрів $[4,5]$.

Метою статті $\epsilon$ викладення результатів порівняльного аналізу інерційних, жорсткісних та дисипативних параметрів динамічних моделей механізмів приводу впускних і випускних клапанів, отриманих за результатами розрахунково-екпериментального дослідження механізмів газорозподілу тепловозних дизелів Д80 та Д49.

Аналіз

пружно-дисипативних параметрів механізмів газорозподілу тепловозних дизелів Д80 та Д49. В рамках динамічного дослідження механізмів газорозподілу тепловозних дизелів особливої складності набуває визначення відповідних жорсткісних (коефіцієнтів 
жорсткості) та дисипативних (коефіцієнтів демпфірування) параметрів елементів конструкції механізмів привода клапанів. Для вирішення цієї задачі в Українській державній академії залізничного транспорту розроблено розрахунково-експериментальну методику, яка базується на використанні дослідних стендів 3 дизелями
Д80 та Д49, а також комплексу вимірювальної та реєструвальної апаратури (рис. 1). В основі експериментальних досліджень закладено створення разових ударних навантажень у відповідних місцях деталей клапанних приводів (рис. 2,3) 3 записом відповідних тензограм загасаючих коливань [7,8].

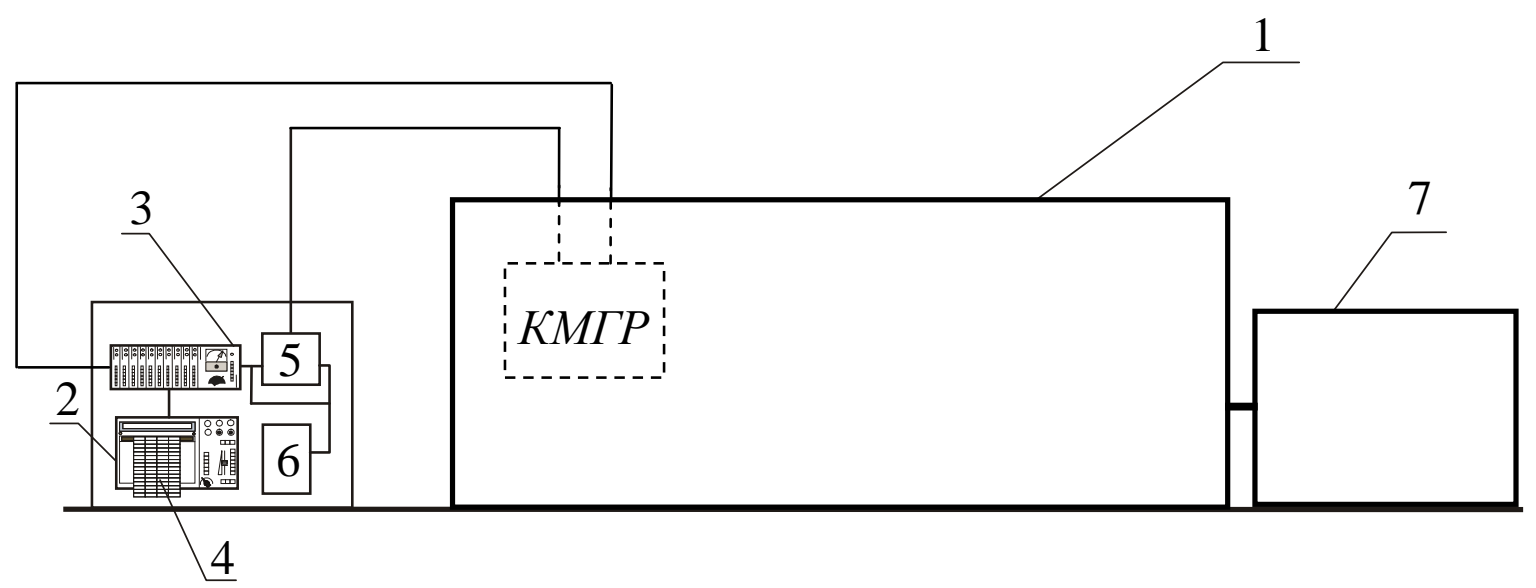

Рис. 1. Схема випробувального стенду:

1 - дизель (Д80, Д49); 2 - світлопроменевий осцилограф «Н 145»;

3 - тензопідсилювач «Топаз - 3»; 4 - паперовий носій з записом тензограм;

5 - блок проміжних перетворювачів; 6 - компенсаційний блок;

7 - навантажувальний пристрій

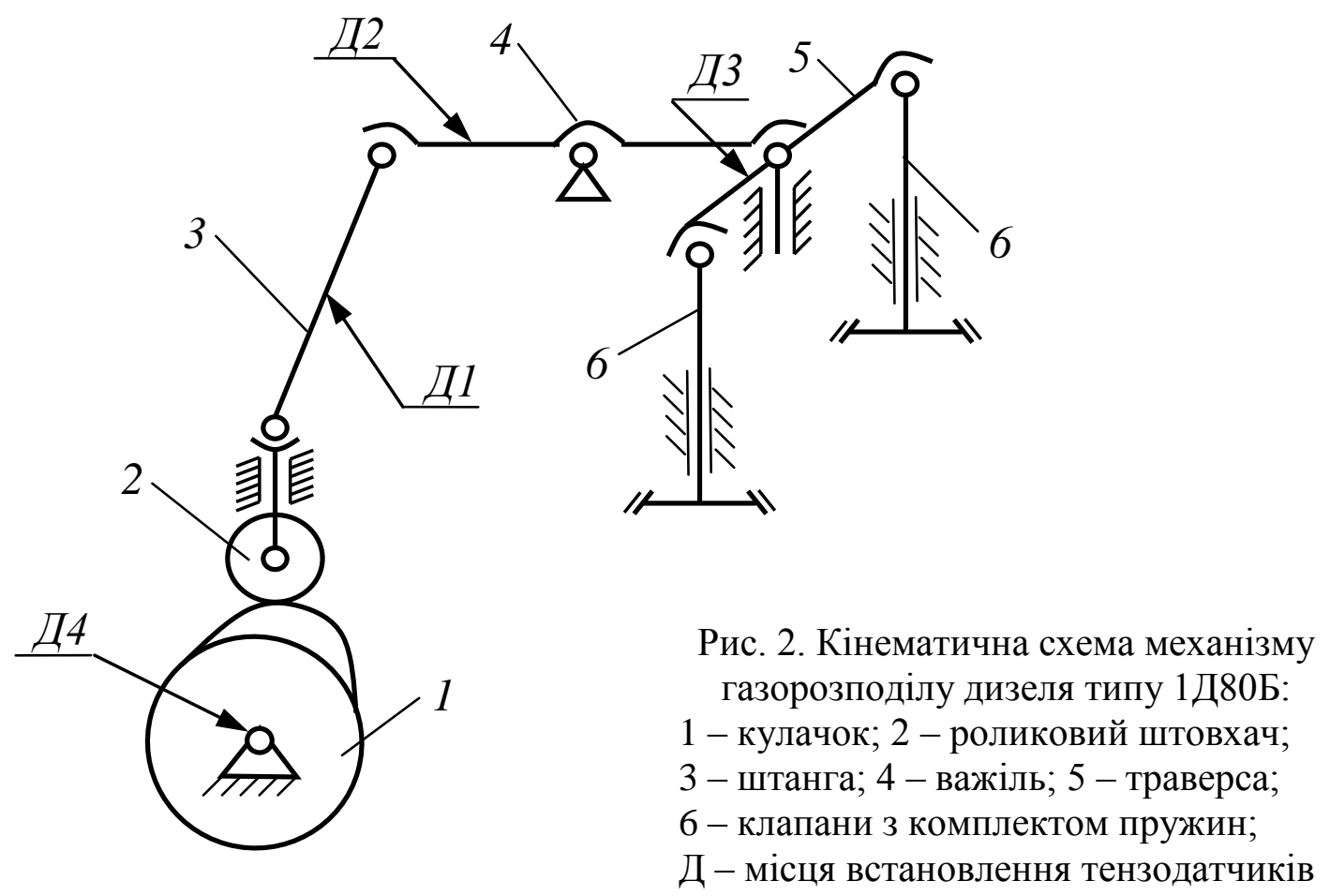




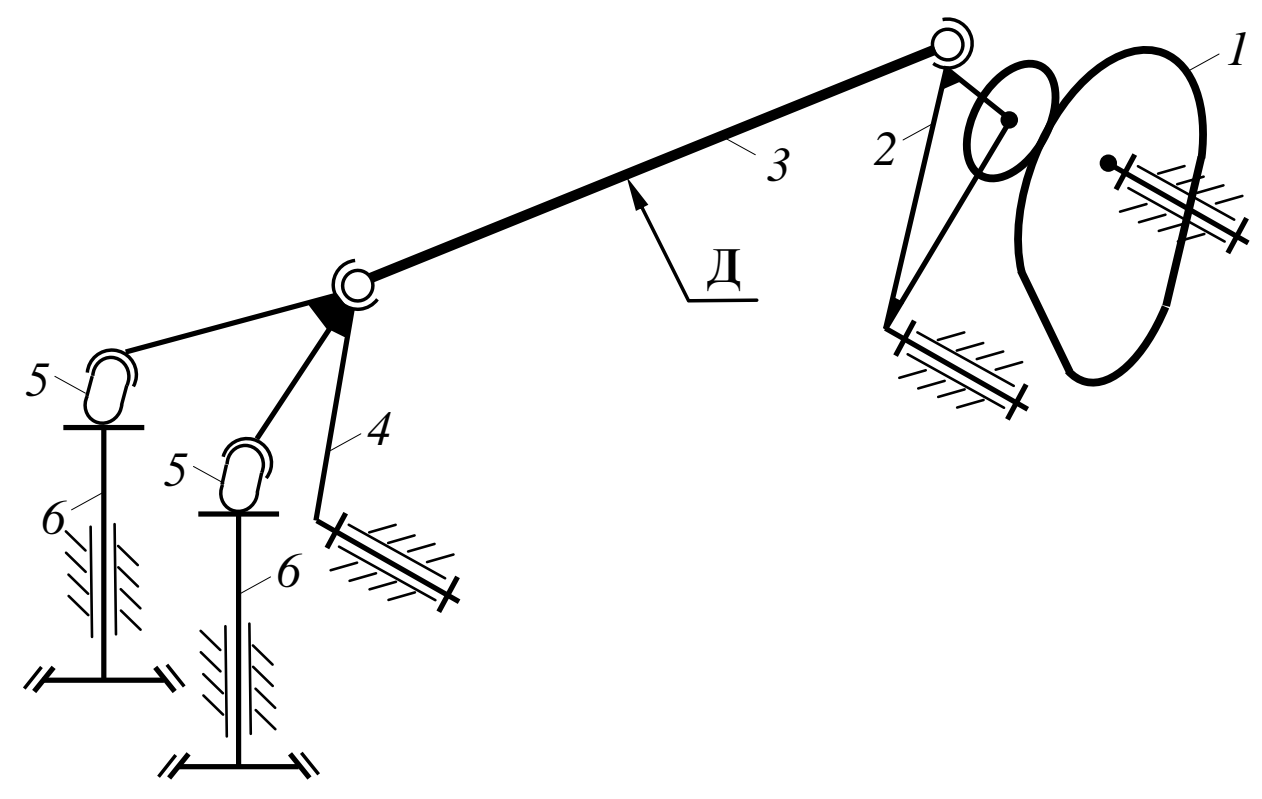

Рис. 3. Кінематична схема механізму газорозподілу дизеля типу 6Д49:

1 - розподільний вал; 2 - коромисловий роликовий штовхач;

3 - штанга; 4 - вильчатий важіль; 5 - гідроштовхачі;

6 - клапани 3 комплектом пружин; Д - місце встановлення тензодатчиків

При проведенні експериментальних досліджень механізмів газорозподілу тепловозних дизелів Д80 та Д49 відтворювалося по 25 вимірювань для приводів впускних та випускних клапанів. Отримані тензограми загасаючих коливань усереднювалися і використовувалися для подальших розрахунків. Їх аналіз дозволив визначити, розрахунковим шляхом, пружно-дисипативні параметри динамічних моделей механізмів газорозподілу тепловозних дизелів Д80 та Д49, які подані в наведеній нижче таблиці.

Порівняльна оцінка поданих в таблиці інерційних, жорсткісних та дисипативних параметрів енергетичних установок тепловозів 3 дизелями Д80 та Д49 показала, що зведена до осі клапана маса рухомих деталей механізму привода впускних та випускних клапанів дизеля 1Д80Б на 5-6 \% більша, ніж для дизеля 6Д49. У свою чергу зведена до осі клапана жорсткість ланок механізму привода впускних клапанів дизеля 1Д80Б на 25\% більша, ніж для дизеля 6Д49, а для привода випускних клапанів - на $40 \%$. При цьому зведений коефіцієнт демпфірування для приводів впускних та випускних клапанів дизеля 1Д80Б у середньому в 1,5 рази більший, ніж для дизеля 6 Д49.

\section{Висновки i перспективи} подальшого використання. Викладені в статті матеріали, а також наведені значення основних пружно-дисипативних параметрів кулачкових механізмів привода клапанів дизелів Д80 та Д49 дозволяють проводити математичне моделювання динамічних процесів їх механізмів газорозподілу на різних експлуатаційних режимах та отримувати відповідні динамічні характеристики, використання яких дозволяе контролювати умови безрозривності кінематичного ланцюга, а також (3 урахуванням динамічних відхилень) отримувати реальні закони руху впускних і випускних клапанів. 
Основні параметри ДМ механізмів привода клапанів дизелів 1Д80Б та $6 Д 49$

\begin{tabular}{|c|c|c|c|c|c|c|}
\hline \multirow{3}{*}{ Найменування } & \multirow{3}{*}{ 密 可 } & \multirow{3}{*}{$\begin{array}{l}\text { Розмір- } \\
\text { ність }\end{array}$} & \multicolumn{4}{|c|}{ Величина } \\
\hline & & & \multicolumn{2}{|c|}{$\begin{array}{c}\text { Привод впускних } \\
\text { клапанів }\end{array}$} & \multicolumn{2}{|c|}{$\begin{array}{c}\text { Привод випускних } \\
\text { клапанів }\end{array}$} \\
\hline & & & 1Д80Б & 6Д49 & 1Д80Б & 6Д49 \\
\hline $\begin{array}{l}\text { Зведена до осі клапана } \\
\text { маса рухомих деталей } \\
\text { механізму }\end{array}$ & $m_{38}$ & кг & 5,64 & 5,31 & 5,45 & 5,18 \\
\hline $\begin{array}{l}\text { Частота власних коливань } \\
\text { механізму }\end{array}$ & $v$ & рад/с & 1480 & 1366 & 1506 & 1309 \\
\hline $\begin{array}{l}\text { Зведена до осі клапану } \\
\text { жорсткість ланок } \\
\text { механізму }\end{array}$ & $c_{36}$ & H/MM & 12270 & 9846 & 12270 & 8815 \\
\hline $\begin{array}{l}\text { Зведений коефіцієнт } \\
\text { демпфірування }\end{array}$ & $k_{36}$ & - & 0,492 & 0,199 & 0,492 & 0,187 \\
\hline $\begin{array}{l}\text { Сила попередньої затяжки } \\
\text { клапанної пружини }\end{array}$ & $F_{0}$ & $\mathrm{H}$ & 1756 & 1396 & 1756 & 1396 \\
\hline $\begin{array}{l}\text { Жорсткість клапанних } \\
\text { пружин }\end{array}$ & $c_{n p}$ & $\mathrm{H} / \mathrm{MM}$ & 84,562 & 60,6 & 84,562 & 60,6 \\
\hline
\end{tabular}

\section{Список літератури}

1. Сергиенко, Н.И. Экономическая эффективность модернизации тепловозного парка Укрзализныци [Текст] / Н.И. Сергиенко, П.С. Скалецкий // Залізничний транспорт України. 1999. - № 3. - С. 16-17.

2. Мороз, В.І. Оцінка резервів поліпшення експлуатаційних показників тепловозних дизелів типу Д80 за рахунок модернізації механізму привода клапанів [Текст] / B.I. Мороз, О.В. Братченко, О.А. Логвіненко // Зб. наук. праць. - Харків: ХарДАЗТ, 2000. - Вип. 41. C.10-13.

3. Мороз, В.I. Розробка динамічної моделі механізму газорозподілу тепловозного дизеля типу Д80 та методика визначення іiі пружно-дисипативних параметрів [Текст] / B.I. Мороз, О.В. Братченко, О.А. Логвіненко // Рухомий склад та спеціальна техніка залізничного транспорту: міжвуз. зб. наук. праць. - Харків: ХарДАЗТ, 2001. - Вип. 46. C. 21-24.

4. Мороз, В.I. Експериментальне визначення пружно-дисипативних параметрів механізму газорозподілу тепловозного дизеля Д80 [Текст] / В.І. Мороз, О.В. Братченко, О.А. Логвіненко // Інформаційно-керуючі системи на залізничному транспорті. - 2002. - № 1. - C. 15-18.

5. Мороз, В.І. Визначення пружньо-дисипативних параметрів динамічної моделі механізму приводу клапанів тепловозного дизеля типу Д80 [Текст] / B.I. Мороз, О.В. Братченко // Підвищення експлуатаційної ефективності тягового рухомого складу залізниці: міжвуз. зб. наук. праць. - Харків: ХарДАЗТ, 2000. - Вип. 11. - С. 80-84.

6. Мороз, В.I. Розробка динамічної моделі механізму газорозподілу тепловозного дизеля типу Д80 та методика визначення ii пружно-дисипативних параметрів [Текст] / 
B.I. Мороз, О.В. Братченко, О.А. Логвіненко // Рухомий склад та спеціальна техніка залізничного транспорту: міжвуз. зб. наук. праць. - Харків: ХарДАЗТ, 2001. - Вип. 46. C. 21-24.

7. Мороз, В.I. Визначення елементів матриць жорсткостей та демпфірування узагальненого рівняння руху клапанів чотиритактних дизелів [Текст] / О.В. Братченко, О.А. Логвіненко, О.В. Надтока // Теплоенергетичні установки та екологія на залізничному транспорті: міжвуз. зб. наук. праць. - Харків: УкрДАЗТ, 2005. - Вип. 70. - С. 101-107.

8. Мороз, В.I. Результати експериментального дослідження механізму газорозподілу локомотивної енергетичної установки типу Д49 [Текст] / О.В. Братченко, О.А. Логвіненко, К.В. Астахова // Зб. наук. праць. - Харків: УкрДАЗТ, 2012. - Вип. 129. - С. 13-19.

Ключові слова: тяговий рухомий склад, тепловоз, дизель, механізм газорозподілу, динамічна модель, тензометрування, пружно-дисипативні параметри.

\section{Анотації}

У статті обгрунтовано, що одним 3 пріоритетних шляхів підвищення паливної економічності та екологічності енергетичних установок сучасних тепловозів $є$ забезпечення ефективного функціонування їх кулачкових механізмів газорозподілу (МГР). Відмічено, що у вирішенні задачі досягнення високих значень часу-перерізу клапанів і забезпечення потрібних фаз газорозподілу одна 3 головних ролей відводиться моделюванню, аналізу і контролю динамічних процесів, які протікають у МГР. Наведено результати порівняльного аналізу інерційних, жорсткісних та дисипативних параметрів динамічних моделей механізмів привода впускних і випускних клапанів тепловозних дизелів Д80 та Д49.

В статье обосновано, что одним из приоритетных путей повышения топливной экономичности и экологичности энергетических установок современных тепловозов является обеспечение эффективного функционирования их кулачковых механизмов газораспределения (МГР). Отмечено, что в решении задачи достижения высоких значений время-сечения клапанов и обеспечения необходимых фаз газораспределения одна из главных ролей отводится моделированию, анализу и контролю протекающих в МГР динамических процессов. Представлены результаты сравнительного анализа инерционных, жесткостных и диссипативных параметров динамических моделей механизмов привода впускных и выпускных клапанов тепловозных дизелей Д80 и Д49.

In article it is proved that one of priority ways of increasing fuel efficiency and ecological compatibility of power plant of modern diesel locomotives is to ensure the effective functioning of their cam gear gas distribution. It is noted that in the task of obtaining high values of the valves' time-sections and providing required valve timing, one of the major roles is assigned to the modelling, analysis and control of dynamic processes that proceed in cam gear gas distribution. Comparative analysis of inertial, stiff and dissipative feature of dynamic models of intake and exhaust valve-actuating gears of diesel locomotive engine D80 and D49 is presented. 